\title{
The Relationship Between the Leadership Styles and the Organizational Climate in Public Schools in Amman
}

\author{
Osama Abdel Fattah ${ }^{1}$, Ayed Zureigat ${ }^{2} \&$ Alaa Elayyan ${ }^{2}$ \\ ${ }^{1}$ The Ministry of Education, Jordan \\ ${ }^{2}$ Faculty of Physical Education, the University of Jordan, Amman \\ Correspondence: Osama Abdel Fattah, The Ministry of Education, Jordan. Tel: 96-27-9959-2069. E-mail: \\ osamhsaf.2811@gmail.com
}

Received: October 1, 2018

Accepted: October 18, 2018

Online Published: November 29, 2018

doi:10.5539/ass.v14n12p97

URL: https://doi.org/10.5539/ass.v14n12p97

\begin{abstract}
This study aimed at identifying the prevailing leadership styles of managers, the organizational environment prevailing in the public schools in Amman, furthermore the relation between these leadership styles and the organizational climate. Thus, the researchers used the descriptive approach on a sample consisting of (55) teachers of the physical education in these schools, of experience between (10-15) years. Collecting the study data, a questionnaire of the leadership style (Shehadeh, 2008) was used after been modified. It consisted of (2) domains (the dictatorial style, the democratic style) with (15) paragraphs. In addition, the questionnaire of (Ahmed, 2008) was modified to measure the organizational climate. It consisted of (4) domains (communication, organization, working conditions, administrative laws) with (20) paragraphs. However, the five-dimensional Likert scale was used in both tools. The results showed that the dominant pattern in the public schools in Amman is the dictatorial pattern, with mean average of (4), which affected the organizational climate in these schools of an average effect of (2.79). The results also showed a positive correlation between the democratic leadership and the organizational climate (0.61). Accordingly, this research concluded that the leadership style based on consultation, participation in decision-making and teachers' personal value esteem has a significant role in the organizational climate.
\end{abstract}

Keywords: communication, leadership styles, organizational climate, public schools

\section{Introduction}

Education is a necessity for human. The renaissance of nations and the progress of humankind rely on. Therefore, educational institutions are the effective instrument for such progress and foe achieving the desired goal (Kaur, 2015; Afolabi, 2005). Where its function and core mission depends on the collective of people working together to achieve common goals, and the presence of effective, Practicable, Inspirational and supportive leadership. This kind of leadership can not only raise teacher's efficiency and productivity, but the whole school, like any organization where there is a series of interactions occur between employees, which in return affect students (Vasquez, 2011 ; Omari et al., 2009). As a social and educational institution, the school aims at providing students with the knowledge, essential experiences to become productive and active members of the society (Almomany, 2006).

Management is an integral part of any organization; In order to increase the effectiveness of the services provided by these institutions, their development and continuation depends largely on the quality of management (Felia \& Abdelhamid, 2005). Meeting the needs of society, management is the key element in the process of reforming and developing education (Abdin, 2004). The educational administration seeks to provide the appropriate circumstances, physical and humanitarian resources needed for the educational process (Ajami, 2008). It represents every activity through which educational purposes are achieve by coordination and guidance of school and educational experiences (Amayra, 2002).

As an educational leader, school principal plays a major role in shaping the constructive organizational climate, through organizing the work, creating the appropriate atmosphere of human relations, encouraging the organizational structure and morals within workers allowing them to share in decision making. All of which contributes to the development of competencies and skills of teachers, along with providing the appropriate communication system (Mustafa, 2005). In this regard, (Salihah, 2010, Sokola et al., 2014) suggest that the 
positive organizational climate helps workers' creativity and rejects routine as it promotes decentralization and the high morale of workers. This climate is heavily influenced by organizational leadership (Allen, 2003).

Where Sharif (2013) stated that, the organizational climate is a mediator between job requirements and the individual needs. It adjusts to the individual tendencies and desires in order to improve performance and productivity and achieve job satisfaction and loyalty (Salihah, 2010). According to Lemaya (2017), employees become associated with educational institution when they are involved in decision-making, and this contributes to self-realization, achievement and motivate. The positive organizational climate contributes to directing the employees' behavior to achieve the objectives of the institution through coordination and integration between the roles they play (Faleh \& Abdelhamid, 2005).

The success of the collective management work requires a wise leadership that supervises the planning of the work and coordinates the efforts of the staff and directing it towards the goals set. It is the link between the organization, its future visions, its plans and its employees to keep abreast of the surrounding developments (Ajami, 2008). While a relationship between the leadership style of school principals and the level of teachers' motivation towards their profession was pointed, and a statistical significant relationship between leadership behavior and motivation for job achievement were detected (Ayasra, 2003; Al-Wadi, 2005).

Leadership concepts are consider organizational climate, workers involvement, job satisfaction. These factors considered as significant in any educational institution and its stability, simply because the performance of the institution depends on the behavior and attitudes of its workforce. The educational institution may have an adequate planning, laws and regulation, but may fail because of the failure of the leadership in accomplishing positive organizational climate (Mudrack, 2004).

Radi (2006) reported that the democratic pattern is the most common among principals' primary public schools in Bahrain. As well, Haykins (2002) confirms that leadership style of managers has a positive relationship and impact on the organizational climate in the educational institutions. This view is consistent with (Sharif, 2013; Shehadeh, 2008; Lasaafi et al., 2016; Noor \& Dzulkitli, 2013) who indicated a statistically significant correlation between leadership styles and organizational climate. Where, Ahmed (2009) indicates a statistically significant correlation between the organizational climate and teacher's motivation level, but Harthy (2009) indicates a positive correlation between organizational climate and job satisfaction.

Identifying the organizational climate prevailing in educational institutions helps in adopting policies that promote positive educational features, eliminate weaknesses, and raise the employees' morals (Amagribi, 2009). Prevailing leadership style in these institutions is a key element of the success and effectiveness of its management. It creates the human interaction necessary to achieve both individual and institutional goals (Al-Omyan, 2004). Moreover, cooperation and social interaction have a positive impact on the constructive organizational climate (Ataweel, 2006). The positive organizational climate contributes also to the work satisfaction and motivation towards achievement (Specter, 2000). Bouhay (2001) reveals that the school administration success bases occur in creating an atmosphere of positive human relations.

Understanding the leadership styles and the organizational behavior of teachers in the educational institutions helps in achieving the objectives of these institutions. Therefore, this study aims at identifying the prevailing leadership styles in the public schools in Amman, and the organizational climate dominated, in addition to the relationship between the adopted leadership style and the organizational climate in these schools. In addition, throughout the school principal, which is the cornerstone of the educational system; researchers suggest that improving the organizational climate of schools is necessary to achieve the desired educational goals.

\section{Materials and Method}

the researchers used the descriptive approach on a sample consisting of (55) teachers of the physical education in public schools in Amman, of experience in teaching ranged between 10-15 years and a managers experience ranged between (10-15). In order to collect the study data, the researchers used the questionnaire as a tool for study. Two questionnaires were used after been modified; the questionnaire of the leadership style of (Shehadeh, 2008), to consist of two domains (the dictatorial pattern, the democratic pattern) with (15) paragraphs and the questionnaire of (Ahmed, 2008) to measure the organizational climate, where It consisted of (4) domains (communication, organization, working conditions, administrative laws) with (20) paragraphs. The questionnaire was distributed by the researchers between 7-23/8/2018, where the questionnaire was handed over to the physical education teacher. After the questionnaire was completed, the questionnaires were collected. However, in order to verify the validity of the study tools, they were judged and reviewed by a (5) of academic professors specialist in the subject directly from the source. Cronbach's alpha was used to estimate the reliability of the sample of study. Table 1 shows the results of the stability coefficient for the areas of study tools. 
Table 1. Demonstrates the results of the stability coefficient for the area of study tools

\begin{tabular}{cc}
\hline Leadership style & Stability coefficient \\
\hline Area & 0.78 \\
Dictatorship pattern & 0.92 \\
Democratic pattern & 0.85 \\
Overall Grade & Stability coefficient \\
Organizational climate & 0.84 \\
Area & 0.75 \\
Communication & 0.85 \\
Organization and Management & 0.88 \\
Work conditions and workload & 0.83 \\
Administrative Laws & \\
Overall Grade & \\
\hline
\end{tabular}

Table 1 . Shows the stability coefficient values for the domains of the study tools, which ranged from $(0.92$ to $0.78)$, where the total stability coefficient of the leadership style was $(0.85)$ and $(0.83)$ for the organizational climate, and all of which are accepted stability coefficients and meet the study objectives. Explaining the results of the study, also table 2. Shows the estimation scale used by the researchers.

Table 2. The estimation scale of the responses of the study sample

\begin{tabular}{|c|c|c|c|}
\hline Scale & Percentage $\%$ & Responses & Score \\
\hline 1 - Less than 1.8 & Less than $36 \%$ & agree very slightly & 1 \\
\hline 1.80 - less than 2.60 & 36. Less than $52 \%$ & agree slightly & 2 \\
\hline 2.60 - less than 3.4 & 52 -Less than $68 \%$ & agree & 3 \\
\hline 3.40 to less than 4.20 & 68 -less than $84 \%$ & agree strongly & 4 \\
\hline $4.20-5$ & 84 and over & agree very strongly & 5 \\
\hline
\end{tabular}

The questionnaires were distributed to the respondents personally. The total number of questionnaire were (63) distributed to the physical education teachers in the public schools in Amman governorate personally, of which (55) questionnaire were valid for analysis. Arithmetic mean, standard deviations, percentages, and Pearson correlation coefficient were used for the analysis of the data collected.

\section{Results}

Figure 1. Shows the mean of physical education teacher's responses to the prevailing leadership style in the public schools in Amman

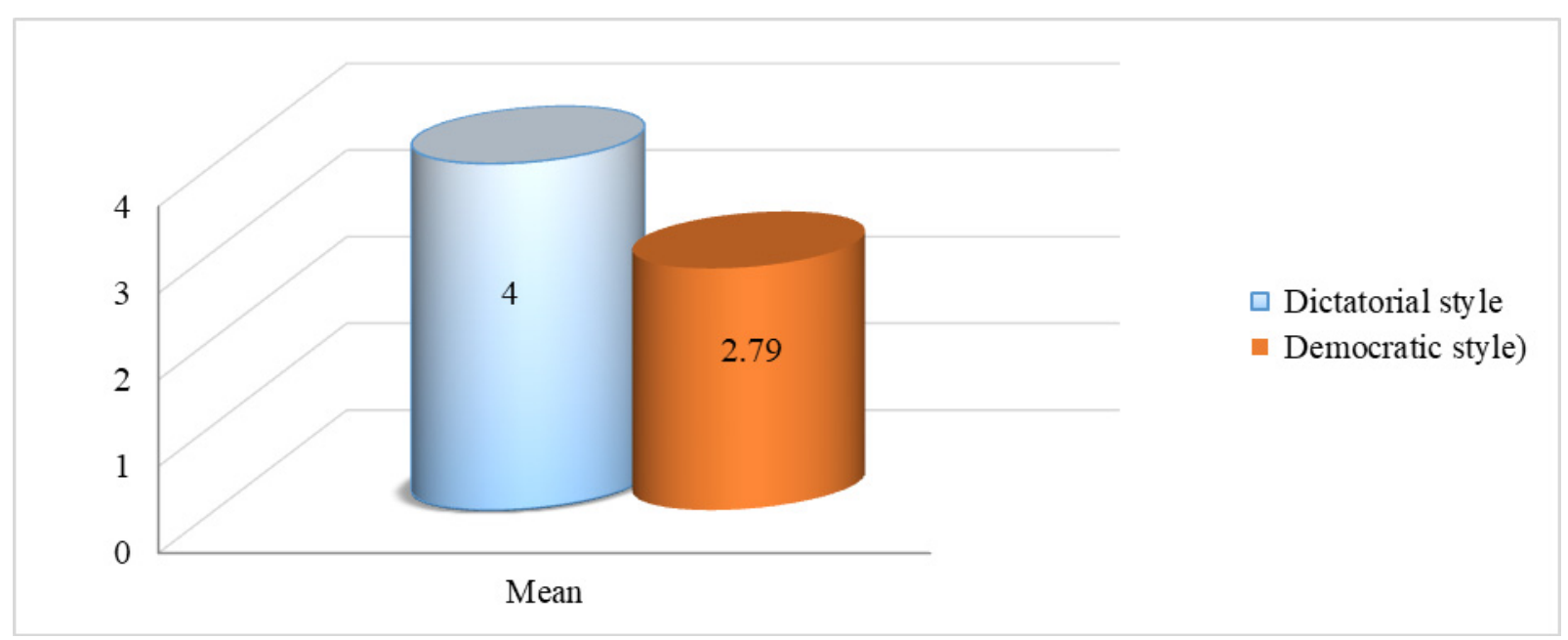

Figure 1. Mean of the prevailing leadership styles in public schools

Figure 2 Shows the means of the responses of physical education teachers to the organizational climate prevailing in public schools in Amman. 


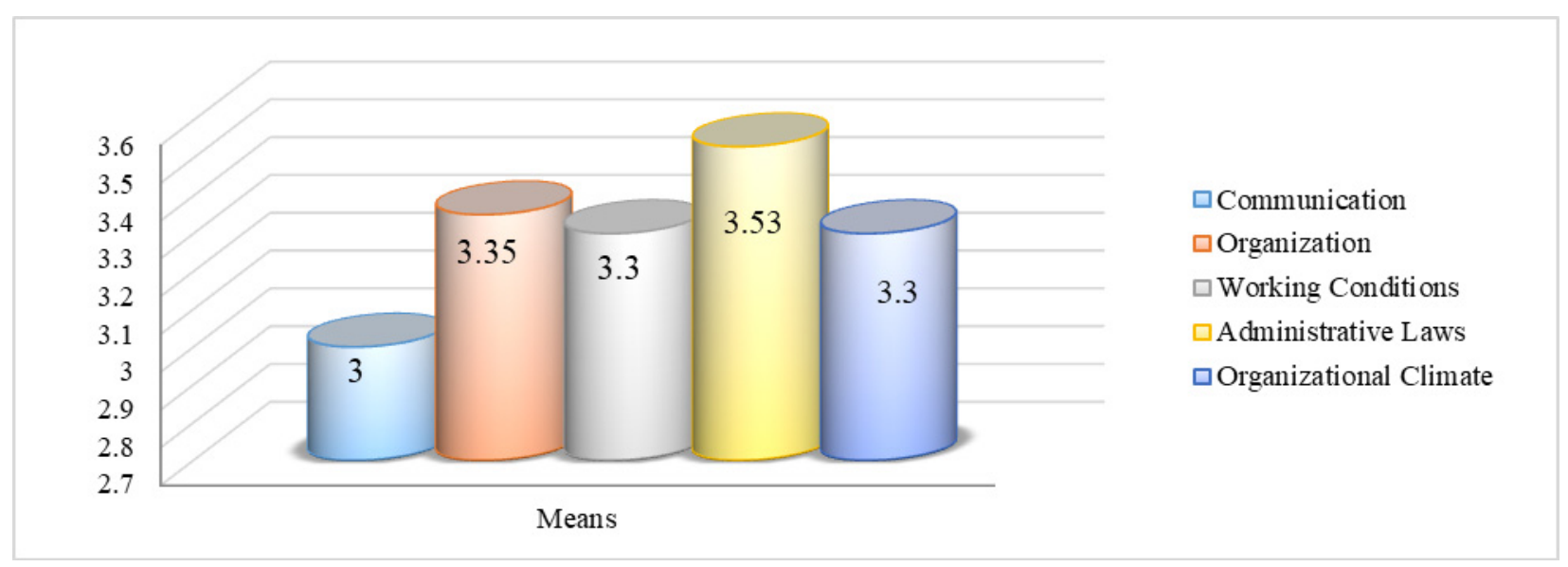

Figure 2. Shows the mean of the regulatory climate areas prevailing in the public schools

In order to establish the relationship between leadership styles in public schools of Amman, the researchers used the Pearson correlation coefficient as illustrated in Table 3.

Table 3. Pearson correlation coefficient values between leadership styles and organizational climate $(n=55)$

\begin{tabular}{cccccc}
\hline $\begin{array}{c}\text { Areas of organizational } \\
\text { climate }\end{array}$ & Communication & Organization & $\begin{array}{c}\text { Work conditions and } \\
\text { workload }\end{array}$ & $\begin{array}{c}\text { Administrative } \\
\text { Laws }\end{array}$ & $\begin{array}{c}\text { A } \\
\text { whole. }\end{array}$ \\
\hline Leadership style & $0.63^{*}$ & $0.55^{*}$ & $0.62^{*}$ & $0.52^{*}$ & $0.61^{*}$ \\
Democratic & 0.25 & 0.45 & 0.22 & $0.54^{*}$ & 0.32 \\
\hline Dictator & 0.25 & &
\end{tabular}

* D statistically at the level of $(\alpha \leq 0.05)$

\section{Discussion}

The results of the current study show the values of the means and the standard deviations of the Dictatorship and Democrat styles, where most of the paragraphs of the dictatorship pattern were high. Paragraph, which stipulates "the school principal requires compliance with the rules and regulations", got the highest rank (4.20), while paragraph, which states that "the principal acts as a representative of teachers at external meetings", got the lowest rank (3.85). In addition, the arithmetic mean of the dictatorial leadership style were relatively high (4). This result is consistent with the responses of the study sample in the area of organizational climate, which has a moderate degree in the areas of communication, organization, working conditions, while the administrative laws ranked relatively high. This type of leadership style may lead to some difficulties for the school administration to perform its functions (Ahmad, 2009), and may affects negatively on the achievement motivation of teachers (Al-Wadi, 2005). Hence, this result does not consistent with the study of (Radhi, 2006) which indicated that the democratic pattern is the most common among principals in public schools in Bahrain. Researchers attribute this result to the principle's goal in accomplishing the work and providing the needs of teachers and develop their abilities rather than paying attention to build social relations with teachers. In this regard, Al-mayyan (2004) points out that the prevailing leadership style in the educational institution is one of the essential elements of the success of its administration, and in creation of the human interaction necessary to achieve the objectives of the teacher and the educational institution alike. Management is the heart of the administrative process by stimulating, throughout motivation, enhancing the morale of teachers, bridging communication bridges and human relations between the management and the school staff. This type of leadership affects the communication process, where it contributes to the quality and flow of work. Good communication involves both upward and downward trends, as it provides workers with opportunities to express opinion and develop (Maher, 2005).

The prevailing patterns of communication create an organizational climate for creativity, innovation and decision-making. Routine leads to boredom and slackness due to the teacher's sense of low importance of work (Al-Omayn, 2004). Moreover, this leadership style affects negatively the cooperative relations between teachers and the administration, which reflected on the performance of the teachers and thus negatively affects the students (Tawil, 2006). This result is contrary to the foundations of successful school management, which is meant to create an atmosphere of positive human relations, that contribute to improve the spirit of teachers, and generate the conditions motivating them (Bouhei, 2001). 
The results also revealed the values of the arithmetical mean and the standard deviations of the domains of the democratic pattern, where most of the paragraphs of this pattern found to be average except for paragraph $(6,7)$, as Paragraph (1) which states that "the school principal participates in the social events", has got the highest average score of (3.20) and an average grade. While paragraph (7), which states, "The school principal provides positive feedback to teachers", has the lowest mean (2.30). The average of the democratic leadership was average also of (2.79). This reflects the concern of principals to apply administrative laws and regulations strictly rather than strengthening the social relations and participations with teachers' social events.

This is evident in the administration's low and sometimes average interest in social participation with teachers and a constructive positive discussion. This administrative behavior was reproduced in the organizational climate prevailing in these schools, which came with an average degree. The researchers attributed this to school administration big attention to the paperwork and the application of laws as is and not the spirit of the law. And maybe the presence of a specific group of teachers close to the school principal have contributed to the this result, as this group keen on taking advantage of its relationship with the school principal by keeping the communication closed with the rest of the teachers. In addition, maybe the burden of huge paperwork required from the principal hinders the application of the democratic style. This result is not consistent with the study of (Radhi, 2006), which indicated that the democratic style is the most common among principals in public schools in Bahrain. On the other hand, this result is consistent with the responses of the sample of the study in the area of organizational climate, which has an average rank in the areas of communication, organization and working conditions.

indicates the values of the arithmetical means of the organizational climate areas prevailing in the Amman public schools, which was average in the areas of communication, organization, working conditions and workload, a high degree of administrative law, and was average (3.30) in this domain as a whole. The area of communication ranked (4), with an average of (3.20), while the arithmetic values of the paragraphs of this area ranged between (3.20 - 2.80). The first paragraph, which states "the principal provides a clear instructions" on the highest arithmetic mean of (3.20), while paragraph (5), which states "the principal allows teachers to contact with officials", has got the lowest mean (2.80). However, work conditions and workload rank was (3) with arithmetic mean of (3.30), and was average, while the mean values of this area ranged between (4.10-2.85) and the middle grade. The second paragraph, which states: (The teacher assigns the teachers the work according to the specialization) on top (4.10) which is average. Paragraph (2), which states "the principal assigns duties to teachers based on their specialty" has got the highest mean (4.10), while paragraph (4) which states" The principal grants teachers' high independence and freedom in performing their work "has got the lowest mean (2.85). The area of organization ranked (2), with a mean of (3.35), while the mean values of its paragraphs ranged between (4.20-2.75) which is average, where paragraph (1) which states that "the principal applies the applicable rules and regulations of the school" has got the highest mean of (4.20) while paragraph (4) which states that "the principal sees feedback necessary for the teachers" obtained the lowest mean of (2.75). As for the administrative laws, it came first, with a mean of (3.53), while the average values of its paragraphs ranged from (4.20-2.80) which is average. Paragraph (1) states" the principal monitors the sing in and out record" got the highest mean of (4.20), while paragraph (4), which states "the principal applies school laws and regulations fairly", has the lowest mean of (2.75). Researchers attribute this to the dominant dictatorial style in these schools, as it is highly practiced, with a focus on work without adequate attention to social relations and communication, as demonstrated by the sample responses in communication and administrative laws domains. This result does not comply with (Mustafa, 2005), who pointed out that the workforce is an important element in upgrading the institutions and its efficiency, and that the organizational climate is associated with teacher motivation (Ahmed, 2009). Al-Harithi (2009) suggests to the positive correlation between organizational climate and job satisfaction. Hence, researchers believe that the principal core role lies in creating a positive organizational climate, which allows the establishment of social and human relations in the organization, raises the morale of teachers, and thus teachers become correlated to work and a part of the school by self-realization and development of self-confidence.

In addition, there are statistically significant correlation between the democratic style and all areas of the organizational climate, where they ranged between $(0.63-0.52)$ and (0.61) for the whole domain. In addition, there is no relationship between statistical relationship between the dictatorial style and all areas of the organizational climate, except for the domain of administrative laws, where the value of this correlation was (0.54). School is considered to be an administrative organization in which the human being is its main factor. It carries out several of activities in light of the existence of participative relationships between its members (Momani, 2006). In this regard, (Salihah, 2010; Sokola et al., 2014) argue that the positive organizational climate 
helps creativity and getting rid of routine; Due to the adoption of decentralization and the high spirit of workers. This climate is heavily influenced by organizational leadership (Allen, 2003).

Lemaya (2017) confirms that employees feel that they are part of the educational institution when they are involved in decision-making, and this contributes to the achievement of self-realization and motivation. The positive organizational climate also orients the employees' behavior to achieve the objectives of the institution through coordination and integration between the roles they play (Faleh \& Abdelhamid, 2005). As to Al-Ayazra (2003), there is a significant relationship between the leadership style of school principals and the level of teachers' motivation towards their profession. Al-Wadi (2005) also indicates a statistically significant relationship between leadership behavior and motivation for job achievement.

According to leadership concepts, organizational climate, employees' engagement, and job satisfaction are very important factors in any educational institution. This is because the institution's performance depends on the behavior and attitudes of its workforce. The institution may have an adequate planning, laws and orders, but it may fail, due to the incompetence leadership and failure in achieving a positive organizational climate (Mudrack, 2004).

While, Radi (2006) reported that the democratic style is the most common among principals in public primary schools in Bahrain. Likewise Haykins (2002) confirms that the leadership styles of principals have significant and a positive relationship with the organizational climate in the educational institutions. This view is steady with (Al-Sherif, 2013; Shehada, 2008; Lasaafi et al., 2016; Noor \& Dzulkitli, 2013) who indicated a statistically significant correlation between leadership styles and the organizational climate.

\section{Conclusions}

The effectiveness and efficiency of individual and teamwork function depend on the organizational climate and its prevailing at the work place. This requires a leadership style based on consultation and participation in decision-making and respect for self-considerations of teachers, of its prominent role in promoting mutual trust and responsibility, thus contributing to the creation of optimistic organizational climate that helps achieve the objectives of the educational institution.

\section{References}

Abdeen, M. (2004). Modern school Management. Dar Al Shorouk Bookshop, Amman, Jordan.

Afolabi, O. A. (2005). Influence of Organizational climate and Locus of Control on Job Satisfaction and Turnover Intentions. IFE Psychology, 13(2), 102-113. https://doi.org/10.4314/ifep.v13i2.23690

Ahmed, A. (2009). The prevailing organizational climate in the public schools of Jerash and its relationship with teachers' motivation. Scientific and Cultural Journal, 32(2), 157-222.

Ahmed, F. (2008). The reality of the organizational climate in the public secondary schools of the directorates of education in the north of Palestine from the point of view of teachers. Master Thesis, An-Najah University.

Ajami, M. (2008). Educational leadership, Effective Educational Supervision, Management and Motivation. New University Publishing House, Alexandria, Egypt.

Al-Amayreh, M. (2002). Principles of School Management. i. Dar Al Masirah, Amman, Jordan.

Al-Ayasra, A. (2003). Leadership styles of the high school principals and the motivation of teachers of the Ministry of Education in Jordan towards their profession. $\mathrm{PhD}$ thesis, Amman Arab University.

Al-Harthy, A. (2009). Organizational climate and its relation to job satisfaction among the principals of the secondary schools of Taif from their point of view. Master Thesis, Umm Al-Qura University, Makkah.

Allen, N. J. (2003). Organizational commitment in the military: A discussion of theory and practice. Military Psychology, 15, 237-253. https://doi.org/10.1207/S15327876MP1503_06

Al-Omari, A., Al-Khasawneh, S., \& Abdullah, A. (2009). The level of satisfaction of faculty members on the academic and the vocational climate in Jordanian universities. University of Damascus Journal, 3(5), 495-529.

Alomyan, H. (2004). Organizational Behavior in Business Organizations (2nd ed.). Amman: Dar Wael for Publishing and distribution.

Al-Sharif, A. (2013). The relationship between educational leadership styles and the organizational climate of the heads of the academic departments at the University of the Western Mountain in Libya. PhD thesis, University of Islamic Sciences, Malaysia. 
Al-Taweel, H. (2006). Educational Administration Concepts and Horizons (3rd ed.). Amman, Dar Wael for Publishing and distribution.

Bouhy, F. (2001). Educational and School Management. Cairo: Dar Kebaa for Printing, Publishing \& Distribution.

Fayla, F., \& Abdel-Majeed, A. (2005). Organizational Behavior in the Management of Educational Institutions. Dar Al Mayser for Publishing, Distribution and Printing, Amman, Jordan.

Haykins, T. (2002). Principal Leadership and Organization Climate: A study of Perceptions Leadership Behavior on School Climate in International School. Dissertation Abstract International, 2(11), 36-39.

Kaur, R. (2015). Influence of Organizational Climate on Job Satisfaction of Elementary School Teacher in Relation to Their Type of School and Gender. Parent Category, 4(1).

La Saafi, Murdjani, K., Adnan, H., \& Ansir. (2016). The Influence of Leadership Style and Organizational Climate on Work Relationship. The International Journal of Engineering and Science (IJES), 5(1), 67-73. https://doi.org/10.9790/1813-0511026773

Lameya, S. (2017). Organizational climate and its impact on job satisfaction. Master Thesis, Faculty of Law, University of Zian Ashour in Djelfa.

Maghribi, A. (2009). Behavioral and Organizational Skills for Human Resources Development. Modern Library.

Maher, A. (2005). An Introduction to Skills Building. Alexandria, Aldar aljameia.

Momani, W. (2006). Organizational climate and conflict management in the educational institutions. Al - Hamed Publishing House and Distribution. Amman, Jordan

Mudrack, P. E. (2004). Job involvement, obsessive-compulsive personality traits and workaholic behavioral tendencies. Journal of Organizational Change Management, 17(5), 490-580. https://doi.org/10.1108/09534810410554506

Mustafa, Y. (2005). Educational Administration, a new entry to a new world. Dar Al-Fikr Al-Arabi, Egypt.

Noor, H. M., \& Bari, A. (2013) Assessing Leadership Practices, Organizational Climate and Its Effect towards Innovative Work Behavior in R \& D. International Journal of Social Science and Humanity, 3(2).

Radi, N. (2006). Leadership styles of principals of primary schools. Journal of Educational and Psychological Sciences, 7(3).

Salihah, S. (2010). Organizational climate and its impact on employees' job performance. Master Thesis, Ahmed Bougara University, Faculty of Economic and Commercial Sciences.

Shehadeh, R. (2008). The relationship between leadership styles and communication patterns among academic managers from the point of view of faculty members of Palestinian universities. Master Thesis, An-Najah University, Palestine.

Sokola, A., Gozdeka, A., Figurskab, I., \& Blaskova, M. (2014). Organizational climate of higher education institutions and its implications for the development of creativity. Procedia - Social and Behavioral Sciences, 182, 279-288. https://doi.org/10.1016/j.sbspro.2015.04.767

Specter, G. (2002). Industrial and Organizational Psychology. New York: Rand N. CNally.

Vasquez, D. (2011). Organizational climate and student achievement in Brazilian secondary schools. Yayımlanmamamıs doktora tezi, Graduate College of the Oklahoma State University.

Wadi, A. (2005). Leadership Behavior of Presidents and its Relation to Motivational Achievement and Job Satisfaction. Journal of Educational and Psychological Sciences, 6(1).

\section{Copyrights}

Copyright for this article is retained by the author(s), with first publication rights granted to the journal.

This is an open-access article distributed under the terms and conditions of the Creative Commons Attribution license (http://creativecommons.org/licenses/by/4.0/). 